\title{
Translation and cross-cultural adaptation of the Brazilian Portuguese version of the Emotional Memory Scale
}

\author{
Tradução e adaptação transcultural da versão brasileira da Escala de Memória \\ Emocional
}

\begin{abstract}
Adam Fijtman, ${ }^{1}$ Letícia Sanguinetti Czepielewski, ${ }^{1}$ Ana Cláudia Mércio Loredo Souza, ${ }^{1}$ Paul Felder, ${ }^{2}$
\end{abstract} Marcia Kauer-Sant'Anna, ${ }^{1}$ Joana Bücker ${ }^{1}$

\begin{abstract}
Background: Emotional memory is an important type of memory that is triggered by positive and negative emotions. It is characterized by an enhanced memory for emotional stimuli which is usually coupled with a decrease in memory of neutral preceding events. Emotional memory is strongly associated with amygdala function and therefore could be disrupted in neuropsychiatric disorders. To our knowledge, there is no translated and culturally adapted instrument for the Brazilian Portuguese speaking population to assess emotional memory. Objective: To report the translation and cross-cultural adaptation of a Brazilian Portuguese version of the Emotional Memory Scale, originally published by Strange et al. in 2003.

Methods: The author of the original scale provided 36 lists with 16 words each. Translation was performed by three independent bilingual translators. Healthy subjects assessed how semantically related each word was within the list (0 to 10) and what the emotional valence of each word was $(-6$ to +6$)$. Lists without negative words were excluded (negative selection), most positive and most unrelated words were excluded (positive and semantic selection, respectively), and lists with low semantic relationship were excluded (semantic assessment).

Results: Five lists were excluded during negative selection, four words from each list were excluded in positive and semantic selection, and 11 lists were excluded during semantic assessment. Finally, we reached 20 lists of semantically related words; each list had one negative word and 11 neutral words.

Conclusion: A scale is now available to evaluate emotional memory in the Brazilian population and requires further validation on its psychometrics properties.
\end{abstract}

Keywords: Cross-cultural comparison, memory, emotions, amygdala.

\section{Resumo}

Introdução: Memória emocional é um tipo importante de memória que é acionado por emoções positivas e negativas. Ela é caracterizada por um aumento de memória para estímulos emocionais que normalmente está associado a um prejuízo de memória para eventos neutros que os precedem. Memória emocional é fortemente relacionada à função da amígdala e, portanto, pode estar alterada em transtornos neuropsiquiátricos. Pelo nosso conhecimento, não existe instrumento traduzido e adaptado culturalmente para a população falante de português brasileiro para avaliar memória emocional.

Objetivo: Descrever a tradução e adaptação transcultural para o português brasileiro da Escala de Memória Emocional, originalmente publicada por Strange et al. em 2003.

Métodos: $O$ autor da escala original forneceu 36 listas com 16 palavras cada. A tradução foi feita por três tradutores bilíngues e independentes. Sujeitos saudáveis foram selecionados para avaliar o quanto cada palavra era semanticamente relacionada dentro da lista (0 a 10) e qual era a valência emocional de cada palavra $(-6 a+6)$. Listas sem palavras negativas foram excluídas (seleção negativa), palavras mais positivas e menos relacionadas de cada lista foram excluídas (seleções positiva e semântica, respectivamente) e listas com relação semântica fraca foram excluídas (avaliação semântica).

Resultados: Cinco listas foram excluídas durante a seleção negativa, quatro palavras de cada lista foram excluídas nas seleções positiva e semântica, e 11 listas foram excluídas na avaliação semântica. Por fim, chegamos em 20 listas de palavras semanticamente relacionadas; cada lista com uma palavra negativa e 11 palavras neutras.

Conclusão: Uma escala está disponível para avaliar memória emocional na população brasileira e requer posterior validação de suas propriedades psicométricas.

Descritores: Adaptação transcultural, memória, emoções, amígdala.

\footnotetext{
${ }^{1}$ Laboratório de Psiquiatria Molecular, Programa de Pós-Graduação em Psiquiatria e Ciências do Comportamento, Universidade Federal do Rio Grande do Sul (UFRGS), Porto Alegre, RS, Brazil. ${ }^{2}$ Washington University in St. Louis, St. Louis, Missouri, USA.

Submitted Oct 13 2017, accepted for publication Dec 122017.

Suggested citation: Fijtman A, Czepielewski LS, Souza AC, Felder P, Kauer-Sant'Anna M, Bücker J. Translation and cross-cultural adaptation of the Brazilian Portuguese version of the Emotional Memory Scale. Trends Psychiatry Psychother. 2018;40(1):61-65. http://dx.doi.org/10.1590/2237-6089-2017-0131
} 


\section{Introduction}

Emotional memory (EM) is defined as an enhanced memory for emotional stimuli which is coupled with a decrease in memory for events preceding those stimuli. ${ }^{1}$ In healthy subjects, EM has already been proven to be associated with amygdala function. In experiments involving lists of words (in which each list contained a word with a negative emotional valence, surrounded by emotionally neutral words), healthy controls tended to have a greater recall of words with a negative emotional valence and a decreased recall of words immediately preceding them. This feature was not seen in the same experiment with patients with amygdala lesions. ${ }^{2}$

The amygdala, a central nervous system structure that is classically associated with emotional control, may be responsible for mediating EM. Strange et al. showed that, in healthy controls, emotional items of a cognitive task are more likely to be recalled than neutral items. Additionally, neutral items that directly precede emotional stimuli are less likely to be recalled than other neutral items. Yet, when these same subjects received propranolol, a beta-blocker medication that acts in the amygdala, enhanced recall of emotional items and deficient recall of preceding items were diminished. ${ }^{2}$ These data corroborate the hypothesis that amygdala lesions may impair a subject from distinguishing if an event has a neutral, positive or negative emotional valence. ${ }^{3}$ Therefore, patients with amygdala dysfunction may attribute a negative emotion to an event that most individuals would consider emotionally neutral.

Neuropsychiatric disorders, specifically those with repercussions in amygdala function, may be associated with changes in EM. Studies have demonstrated EM changes in patients with bipolar disorder. ${ }^{4}$ Amygdala function and EM may be important markers of neurological and psychiatric disorders. However, to the authors' knowledge, a scale to assess EM had so far not been translated to Brazilian Portuguese and culturally adapted.

Therefore, the objective of this study was to describe the creation of a Brazilian Portuguese translation and cross-cultural adaptation of the Emotional Memory Scale originally published by Strange et al. ${ }^{3}$

\section{Methods}

Permission to cross-culturally adapt the scale to Brazilian Portuguese was requested from the original author of the Emotional Memory Scale. We also asked for a full list of words used in his experiments. The author of the original scale sent us 36 lists, each with 16 words, in English. Words from each list were semantically related and each list contained a word with a negative valence. After obtaining permission and the lists, we began a five-step validation process: translation, negative selection, positive selection, semantic selection and semantic assessment.

Translation was done by two independent bilingual translators ( $\mathrm{T} 1$ and $\mathrm{T} 2$ ) who had had no previous contact with the lists of words. Next, a third independent translator (T3) compared the translations and resolved differences.

A group of healthy controls were recruited from a population of volunteer blood donors at blood bank program of Hospital de Clínicas de Porto Alegre. Inclusion criteria were age 18-60 years, not fulfilling criteria for any psychiatric diagnosis according to the Diagnostic and Statistical Manual of Mental Disorders, 4th edition (DSM-IV) (checked with Structured Clinical Interview for DSM-IV Axis I Disorders - SCID-I), a negative history of psychiatric and neurological disorders, and a negative history of psychiatric disorders in first-degree relatives.

Each subject received two copies of the 36 lists of 16 words each. In the first copy, each subject was asked to assign a score to the emotional valence of the word, from -6 to +6 ( -6 to -3 was considered negative, -2 to +2 was considered neutral, and +2 to +6 was considered positive). In the second copy, each subject had to assign a score from 0 to 10 on how semantically related each word was compared to other words from the list ( $0=$ not semantically related, $10=$ completely semantically related). After that, we calculated the mean emotional valence of each word, the mean semantic relationship of each word, and the mean semantic relationship of each list.

In the step of negative selection, lists that did not have any words with a mean negative emotional valence were excluded. In the step of positive selection, we excluded the two most positively ranked words from each list. Semantic selection consisted of excluding the two most semantically unrelated words from each list. Finally, semantic assessment excluded lists with a lower mean semantic relationship.

Figure 1 illustrates the translation and adaptation process. We followed instructions from the author of the original scale, who used a similar process in the translation of the scale to other languages. ${ }^{2}$

All study procedures were approved by the research ethics committee of Hospital de Clínicas de Porto Alegre. Written informed consent was obtained from all subjects prior to their inclusion in the study.

\section{Results}

During the translation step, there was variation in the translations done by $\mathrm{T} 1$ and $\mathrm{T} 2$. T3 resolved 
these differences by selecting the translation that best correlated to the original meaning of the word. Also, T3 chose the word he assumed would be best understood by members of the population under investigation.

For the remaining steps, we included 11 healthy subjects, a number that is similar to the number of people used to create the original scale and to translate it to other languages. ${ }^{2}$ Mean age was 27.3 years (standard deviation $=3.634$ ), mean years of education was 13.4 (SD $=2.416)$, and $\operatorname{six}(54.54 \%)$ of the subjects were women. Our study population had similar characteristics to that of the original study that validated the English scale.

Five out of 36 translated lists did not have any words considered emotionally negative, therefore these lists were excluded during negative selection. The two most positive words from each list were excluded during the positive selection step. The two least related words from each list were excluded during semantic selection. Eleven lists were excluded during semantic assessment due to the low semantic relationship between the words.

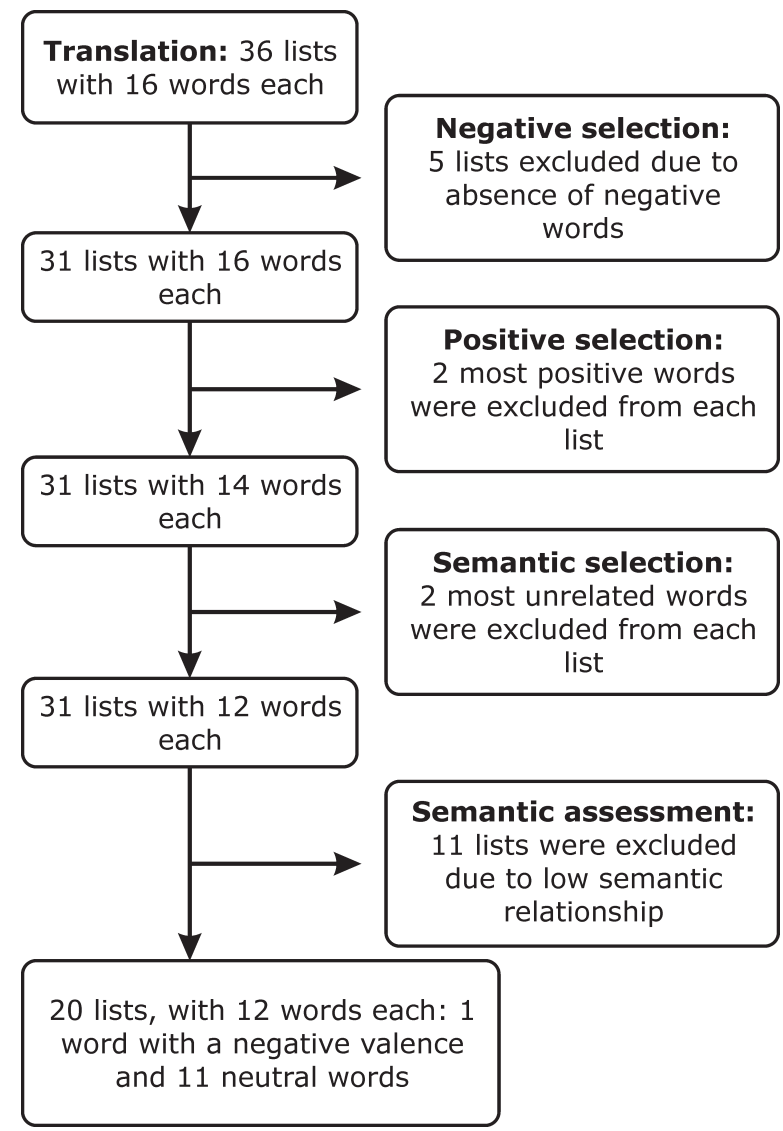

Figure 1 - Five steps of the translation and cross-cultural adaptation process of the Emotional Memory Scale
At the end of the five steps, we concluded that 20 lists with 12 words each were valid for use in the Brazilian Portuguese population. Each list has one word considered to be emotionally negative (mean emotional valence between -6 and -3 ) and 11 words considered to be emotionally neutral (mean emotional valence between -2 and +2 ). Words from each list were semantically related.

The final version of the Emotional Memory Scale translated and culturally adapted to Brazilian Portuguese is shown in Figure 2. Words considered to have a negative valence are marked with (E). The other 11 words from each list were considered emotionally neutral.

\section{Discussion}

Several studies have demonstrated a cognitive deficit in patients with psychiatric disorders. ${ }^{5}$ These impairments were already established in diagnoses like bipolar disorder, ${ }^{6}$ major depressive disorder ${ }^{7}$ and schizophrenia ${ }^{8}$ and could be explained by changes in the hippocampus, frontal cortex and amygdala. Studies of cognition in psychiatric disorders are useful to better understand mental illness and to develop new treatments to improve the functionality and well-being of patients.

EM is a cognitive domain which may be altered in patients with bipolar disorder. ${ }^{4}$ There is evidence that memory for emotional events may require specific neuroanatomical circuits, which include the amygdala. Also, there is reason to believe that processing of emotions may be disrupted in patients with bipolar disorder: many symptoms associated with mood episodes are controlled by pathways common to emotional processing. ${ }^{9}$

Strange et al. ${ }^{3}$ developed a scale to assess EM in healthy subjects and proved that EM was impaired after treating these subjects with propranolol, a beta-blocker that acts in the amygdala. His scale has also been translated to German. ${ }^{2}$ However, to our knowledge, this scale has not been tested in patients with bipolar disorder: it would be interesting to do so in order to investigate possible EM changes, compared to EM changes in healthy subjects treated with propranolol. Furthermore, it would be interesting to apply this scale in patients with other psychiatric diagnoses, like major depressive disorder and schizophrenia, in order to assess possible changes in emotional circuits.

Working with two translators and a third blind translator during cross-cultural adaptation of the Emotional Memory Scale helped to reach satisfactory semantic equivalence to the original instrument. This method also ensured that 
differences between two translations were reconciled to define appropriate translation.

Semantic selection and semantic assessment were important to reach a final list of words which were considered semantically related by healthy controls in our social environment. Negative selection and positive selection were important to verify that the final lists had 11 emotionally neutral words and 1 word considered emotionally negative by our population. Having completed these steps, we believe that the scale is now suitable for research on EM in Brazilian Portuguese speakers.

Study limitations include a small number of participants; however, sample size was similar to studies that validated the scale to other languages. It is also important to note that our methods involved only translation and cross-cultural adaptation. Future studies may corroborate validation of the scale. Furthermore, another limitation of the study would be potential cultural differences between different regions of Brazil: our study population was entirely recruited at the same hospital.

Cross-cultural adaptation is a fundamental step when translating a scale. ${ }^{10,11}$ The Emotional Memory Scale designed by Strange et al. had already been translated and adapted to German and has been used in important studies about cognition. ${ }^{2}$ The Brazilian version of the
Emotional Memory Scale may significantly contribute to this field of study. Future studies should assess the reliability of the instrument.

\section{Conclusion}

This study described cross-cultural adaptation of the Emotional Memory Scale to Brazilian Portuguese. Five steps were followed, according to the recommendations from the author of the original scale: translation, negative selection, positive selection, semantic selection and semantic assessment. As a result, 20 lists of words were determined, each containing 11 neutral words and 1 word with an emotionally negative valence. The Emotional Memory Scale is considered adequate for use in the Brazilian population, and we believe it will fill a significant gap in this field of study, contributing to the development of future studies about EM in psychiatry.

\section{Acknowledgements}

This study was funded by Coordenação de Aperfeiçoamento de Pessoal de Nível Superior (CAPES) and Conselho Nacional de Desenvolvimento Científico e Tecnológico (CNPq).

\begin{tabular}{|c|c|c|c|c|c|c|c|c|c|}
\hline List 1 & List 2 & List 3 & List 4 & \begin{tabular}{|l|} 
List 5 \\
\end{tabular} & List 6 & List 7 & List 8 & List 9 & List 10 \\
\hline condutor & comício & articulação & boca & gelo & gengiva & janela & olho & trabalho & carvão \\
\hline pedestre & pessoa & quadril & nariz & chuva & flúor & mansão & panorama & químico & gás \\
\hline passageiro & comunidade & calcanhar & oxigênio & lancha & dente & proprietário & vídeo & bancário & caldeira \\
\hline caminhão & reunião & cotovelo & inalação & nublado & saliva & condomínoi & vista & físico & vapor \\
\hline camionete & congresso & pulso & pulmão & casaco & pasta & morado & cena & ocupação & tubulação \\
\hline carro & simpósio & membro & respiração & cidade & canino & apartamento & imagem & advogado & (E) explosão \\
\hline (E) acidente & congregação & joelho & vento & boia & mandíbula & porta & visão & engenheiro & fogão \\
\hline ônibus & assembléia & tornozelo & sopro & córrego & (E) afta & garagem & ótica & ator & temperatura \\
\hline rua & aglomeração & ombro & ventilação & (E) enchente & molar & casa & cinema & vocação & aquecedor \\
\hline motorista & (E) massacre & braço & (E) sufocamento & luva & oral & chalé & (E) cegueira & (E) assassino & fogareiro \\
\hline estrada & empresa & (E) amputação & narina & prancha & labial & (E) arromabamento & observador & contador & lenha \\
\hline avenida & escritório & pé & ar & frio & escova & sobrado & lupa & ofício & forno \\
\hline List 11 & List 12 & List 13 & List 14 & List 15 & List 16 & List 17 & List 18 & List 19 & List 20 \\
\hline criança & $\sin \circ$ & palma & estação & pijama & ferramente & educador & construção & rio & adubo \\
\hline pai & missa & nervo & baile & dormitório & polir & educação & mirante & lagoa & colina \\
\hline berço & crença & dedo & festival & lua & parede & professor & telhado & canoa & solo \\
\hline gravidez & convento & tato & estádio & anoitecer & metal & escola & pico & piscina & cascalho \\
\hline mamadeira & padre & corpo & show & travesseiro & madeira & faculdade & torre & balsa & jardineiro \\
\hline cesariana & culto & pele & cobrador & quarto & ferro & (E) reprovação & (E) suicídio & baía & chão \\
\hline parto & capela & toque & (E) traficante & sono & martelo & colégio & ponte & (E) afogamento & rocha \\
\hline bebê & pastor & sensação & boate & lençol & (E) crucificação & aula & penhasco & nadador & terreno \\
\hline nascimento & igreja & textura & rodoviária & cobertor & carpinteiro & universidade & altura & riacho & (E) cadáver \\
\hline gestação & (E) diabo & superfície & público & escurecer & parafuso & acadêmico & sacada & barco & raiz \\
\hline (E) aborto & templo & (E) dor & metrô & (E) pesadelo & prego & tutor & alto & água & terra \\
\hline chupeta & bíblia & vibração & turma & camisola & serrote & prova & prédio & areia & escavação \\
\hline
\end{tabular}

Figure 2 - Emotional Memory Scale translated and culturally adapted to Brazilian Portuguese.

$(E)=$ word with negative emotional valence. 


\section{Disclosure}

No conflicts of interest declared concerning the publication of this article.

\section{References}

1. Christianson S- $\AA$. The handbook of emotion and memory: research and theory. Mahwah: Erlbaum; 1992.

2. Strange BA, Hurlemann R, Dolan RJ. An emotion-induced retrograde amnesia in humans is amygdala- and beta-adrenergicdependent. Proc Natl Acad Sci U S A. 2003;100:13626-31.

3. Strange $B A$, Dolan RJ. Adrenergic modulation of emotional memory-evoked human amygdala and hippocampal responses. Proc Natl Acad Sci U S A. 2004; 101:11454-8.

4. Kauer-Sant'anna M, Yatham LN, Tramontina J, Weyne F, Cereser $\mathrm{KM}$, Gazalle FK, et al. Emotional memory in bipolar disorder. $\mathrm{Br}$ ] Psychiatry. 2008;192:458-63.

5. Bora E, Pantelis C. Meta-analysis of cognitive impairment in first-episode bipolar disorder: comparison with first-episode schizophrenia and healthy controls. Schizophr Bull. 2015;41:1095104.
6. Samamé C, Martino DJ, Strejilevich SA. An individual task metaanalysis of social cognition in euthymic bipolar disorders. J Affect Disord. 2015;173:146-53.

7. Bora E, Berk M. Theory of mind in major depressive disorder: A meta-analysis. J Affect Disord. 2016;191:49-55.

8. McTeague LM, Huemer J, Carreon DM, Jiang $Y$, Eickhoff $S B$, Etkin A. Identification of common neural circuit disruptions in cognitive control across psychiatric disorders. Am J Psychiatry. 2017;174:676-85.

9. Phillips ML. Understanding the neurobiology of emotion perception: implications for psychiatry. Br J Psychiatry. 2003;182:190-2.

10. Gjersing L, Caplehorn JR, Clausen T. Cross-cultural adaptation of research instruments: language, setting, time and statistical considerations. BMC Med Res Methodol. 2010;10:10-3.

11. Cantini JA, Santos GO, Machado Ede C, Nardi AE, Silva AC. Translation and cross-cultural adaptation of the Brazilian Portuguese version of the Driving Anger Scale (DAS): long form and short form. Trends Psychiatry Psychother. 2015;37:42-6.

\section{Correspondence:}

Adam Fijtman

Laboratório de Psiquiatria Molecular, HCPA, CPE

Rua Ramiro Barcelos, 2350, térreo

90035-903 - Porto Alegre, RS - Brazil

Tel. : +55 (51) 984197763

E-mail: adamfijtman@gmail.com 